\title{
Problem Faced by the Large Cardamom Growers during Production and Marketing: A Case Study of Tirap District of Arunachal Pradesh, India
}

\author{
Avicha Tangjang and Amod Sharma*
}

Nagaland University, SASRD, Medziphema Campus, District: Dimapur, Nagaland, India

*Corresponding author

\begin{tabular}{|c|}
\hline \\
\hline $\begin{array}{l}\text { Large cardamom, } \\
\text { Socio-economic, } \\
\text { Status, Land use } \\
\text { pattern, Constraints }\end{array}$ \\
\hline Article Info \\
\hline $\begin{array}{l}\text { Accepted: } \\
18 \text { April } 2018 \\
\text { Available Online: } \\
10 \text { May } 2018\end{array}$ \\
\hline
\end{tabular}

A B S T R A C T

A research study of the large cardamom growers in Tirap district of Arunachal Pradesh to highlight the problem faced during the production and marketing was conducted during the year 2014-2015, wherein, a hundred numbers of large cardamom growers were selected from four different villages by following stratified simple random sampling method. The selected farmers were classified into three groups based on their total land under large cardamom cultivation viz. Category-I (0.10-0.50 ha), Category-II (0.51 to 1.46 ha) and Category-III (= 1.47 ha $<$ ). The study reveals that 49.00 per cent of the respondents belonged to the age group of below 40 years, followed by 39.00 per cent in the middle age group between 41-60 years and 12.00 per cent in the old age group above 61 years, the male: female ratio of 0.96 with a literacy rate of (72.17 per cent) and an illiteracy rate of (27.83 per cent) was observed. The earners constituted about 34.79 per cent of the total sample. 94.00 per cent of the respondents practiced agriculture as their primary occupation and the average size of land holding for the respondents was found out to be 10.20 ha/family. A large portion of about 84.58 per cent of the total land was found to be under jhum cultivation with an average of 8.65 ha / household and the average area of 1.01 ha / family under large cardamom cultivation. The average yield per hectare was found to be $345.35 \mathrm{~kg} / \mathrm{ha}$. While some of the major problems faced by the large cardamom growers viz; lack of knowledge and training in scientific methods of cultivation, post harvest losses, unawareness about market information, pest and disease incidence and their management etc.

\section{Introduction}

Black cardamom, also known as hill cardamom, Bengal cardamom, greater cardamom, Indian cardamom, Nepal cardamom, winged cardamom, or brown cardamom, comes from either of two species in the family Zingiberaceae. This spice has a camphor-like flavor, with a smoky character derived from the method of drying. There are two distinct species of black cardamom i.e; Amomum subulatum and Amomum tsao-ko. The pods of Amomum subulatum, are comparatively smaller and used primarily in the cuisines of India and certain regional cuisines of Pakistan, whereas, Amomum tsao$k o$ has larger pods and are used primarily in in Chinese cuisine, and Vietnamese cuisine (Wikipedia). Large cardamom is one of the world's most ancient spices and is a perennial 
soft stemmed low-volume, high-value crop (Avasthe et al., 2011).

Large cardamom originated in Sikkim (India) and is grown only in the eastern Himalayan countries viz., Nepal, northeast India, and Bhutan (Sharma et al., 2009). Large cardamom grows abundantly in hills, but often without following any scientific agrotechniques. However this area demands greater attention to have a sound value chain of this unique crop (Bhutia et al., 2018). The large cardamom trade involves a number of intermediaries between producers (farmers) and consumers. Export price fluctuation is the major problem for farmers and traders. Marginal farmers used to take advances from local traders before the harvest season and repay the amount with interest by selling their products to them (Bhutia et al., 2018). Another system is the dahadani, the selling of crops in the field to local merchants, in which farmers display the harvested produce after drying (Stoep, 2010).

The Indian large cardamom market has a complex structure where the product inflow and outflow take place simultaneously. However, it is apparent that a large quantity is consumed in the domestic market, as the Indian export volume is comparatively low. The Spices Board of India controls and monitors the spice trade in this country. Local dealers or wholesalers collect dried large cardamom capsules from the farmers, perform minimal quality grading, and sell in bulk to exporters. In this system, the price of the commodity is fixed between the farmer and the local dealer, and farmers are usually paid less than the market average (Bhutia et al., 2018). According to Sharma et al., (2009) large cardamom production has declined in recent years and one of the main reasons for this is viral diseases like chirkey and phurkey (Stoep, 2010) and also using the same planting material year year after year (Bhutia et al.,
2018). Another major problem is the difficulty in adopting improved curing methods known to produce higher-quality capsules due to inability to afford improved bhattis. Moreover, these bhattis are designed to be used only for one harvesting season in a year, and hence, it is difficult for farmers to pay back the costs invested (Bhutia et al., 2018). Lack of effective grading mechanisms also limits farmers' ability to charge higher prices for their products. Market channelization for quality capsules is also a major challenge (Sharma et al., 2009).

However, many governmental organizations and NGOs are being engaged to encourage large cardamom farming in the sub-Himalayan region, such as the National Cardamom Development Center and the Netherlands Development Organization in Nepal. In India, the Indian Cardamom Research Institute, Department of Horticulture and Cash Crop Development, Government of Sikkim, and North Eastern Regional Agricultural Marketing Corporation are providing supports in crop development, postharvest technology, and marketing (Bhutia et al., 2018).

Commercial cultivation of large cardamom in the Tirap district of Arunachal Pradesh is relatively new and has been brought under practice only in the past decade. However, it holds great potential and is rapidly gaining widespread popularity with about 310 ha under the cultivation of the particular crop in the year 2013-2014. This has led to the rapid transition from the traditional small scale subsistence farming practiced by the locals to commercial farming; owing to the low volume, high value characteristics of the crop.

\section{Materials and Methods}

Keeping in view the status of large cardamom cultivation in the Tirap district of Arunachal Pradesh and the prospects it holds in 
improving the socio-economic status of the local people in the future, the study was undertaken under the following objectives.

(i) To study the socio-economic condition of large cardamom growers.

(ii) To study the constraints faced by large cardamom growers during the marketing of large cardamom and to suggests the ways and means to over the problems.

The study was conducted on the cardamom growers and sellers in the Tirap district of Arunachal Pradesh for which two blocks viz. Lazu and Dadam were purposefully selected for the study due to the presence of large number of large cardamom growers.

A list of villages growing large cardamom commercially from the two selected blocks was obtained, and four villages were selected from the list using random sampling method.

A lists of large cardamom growers were then obtained from the village heads and village elders of the respective villages and twentyfive large cardamom growers from each village were selected using simple random sampling method to obtain a list of onehundred respondents to be interviewed using a predesigned set of questionnaires.

The study was based on the primary and secondary data of the various socio-economic and demographic characteristics of the farmers, marketing channels, marketing costs, marketing margins, price spreads, marketing efficiency and constraints faced by the farmers from the selected households. The secondary data was collected from the office of the D.A.O. of Tirap, office of the NERCORMP, Khonsa, etc. The primary data was collected with the help of structured and pre- tested questionnaires and schedules through personal interview method.

\section{Analytical techniques and tools:}

Collected data was scrutinized, tabulated and processed systematically according to the objectives laid down for the study. Tabular and functional analysis was used to meet the objectives of the study as and where needed.

\section{Socio-economic condition of the large cardamom growers}

Data on the demographic features, land use pattern, area under irrigation, literacy, occupation etc. was obtained for the respondents and their family members by using structured and pre- tested questionnaires through personal interview method.

\section{Constraints in production and marketing of large cardamom crop}

The response of the farmers to various constraints faced in production and marketing of large cardomom was obtained and ranked through frequency in order to examine the constraints.

\section{Results and Discussion}

The data obtained by interviewing the respondents was then subjected to various statistical tools and graphs with reference to the set objective in order to obtain a general understanding of the sample population. According to the data collected, the respondents were divided into three categories depending on the land under large cardamom cultivation by the method of grouping the ungrouped data by using mean and standard deviation.

In an attempt to study the socio-economic status of the selected farmers, it was found that 49.00 per cent of the respondents belonged to the age group below 40 years followed by 39.00 per cent in the age group 
between 41-60 years and 12.00 per cent in the age group above 61 years. This pattern could be explained by the fact that younger people are mentally and physically more sound and can perform physical work better and can make sound choices and decisions in life.

The study showed that 88 percent of the respondents were male and the 12 per cent were female. And while bringing all the members of the respondent's family under consideration, it was observed that 247 were male and 256 were female. The male: female ratio was found to be 0.97 for both category-I and category-II and 1.24 for category-III. The overall ratio came out to be 1.04 . From this, we can deduce that there are more females than males among the families on which the study was carried out.

A total of twenty six (26) families were enlisted in Category-I, forty five (45) families in Category-II and twenty nine (29) families in Category -III. The average size of the family was found to be 5.38 for category-I, 5.13 for category-II and 4.55 for category-III. The average number of adult males per family was found to be 2.08, 1.93 and 1.69 for category-I, category-II and category-III respectively. The average number of adult females per family was found to be $1.88,1.96$ and 1.62 for category-I, category-II and category-III respectively and, the average number of children per family was found to be 1.42 for category-I, 1.24 for both category-II and category-III. Thus, it was observed that the farm family comprised mostly of five members.

The largest size of family was nine (9), eight (8) and seven (7) for category-I, category-II and category-III respectively and the smallest size of family for category-I, category-II was found to be three (3) and category-III was found to be two (2). Considering the twenty six (26) families in category-I, it was observed that 38.57 percent were males, 35.00 percent were female and 26.43 percent were children. For category-II, 37.66 percent were males, 38.10 percent were female and 24.24 percent were children. For category-III, 37.12 percent were males, 35.61 percent were female and 27.27 percent were children.

The study found that 40.00 per cent of the respondents were illiterate, 49.00 per cent were educated till primary level and only 11.00 per cent were educated at high-school level. Also, while taking the whole family of the respondents under consideration, it was found that 27.83 per cent of the sample were illiterate, 47.12 per cent were found to be educated to primary level, 23.66 per cent till high-school level and a mere amount of 1.39 per cent till graduation level. It was observed that almost half of the sample under study quit schools after primary level followed and a quarter of the sample quitting after high school level. This pattern can be explained by the fact that the villages under study are located away from the main town and the schools in the villages are generally only till primary level and have few schools till high school level, and villagers generally cannot afford to send their children outside of the village.

Earners constitute about 34.79 per cent of the total sample. The percentage of earners in different categories was found to be, 34.29 per cent in category-I, 33.77 per cent in categoryII, and 37.12 per cent in category-III. It was observed that 31.00 per cent of the sample was earner dependent and 59.04 per cent was dependent. It was observed that only 40.95 per cent of the total sample under study constituted the working force and earned for their family, whereas, a large portion of 59.05 per cent were totally dependent on the earners. 94.00 per cent of the farm families were found to have adopted agriculture as their primary occupation followed by 4.00 per cent adopting 
service and 2.00 per cent adopting business as their primary occupation. Secondary occupation of the farm families under study mainly constituted of odd jobs like hired labour and daily waged labour, with 45.16 per cent of the farm families engaging in such activities followed by 32.26 per cent engaging in business and 22.58 per cent in agriculture.

The Tirap district of Arunachal Pradesh is blessed with and ample amount of farming land and rainfall throughout the year. The primarily dependence of the local people on agriculture for their living, satisfactory yield with minimum input in the farm, availability of local market along with many other related factors like lack of educational qualification and lack of entrepreneurial qualities could be considered as the primary factors that come to play leading the villagers to be primarily involved in agriculture.

A tiger's share of the total landholding was found to be utilized for jhum cultivation and only a small portion of the total landholding was allocated to other agricultural as well as non agricultural uses.

It was observed that 84.58 per cent of the land was under jhum 1.36 per cent under lowland cultivation, 9.90 per cent under large cardamom cultivation, 0.81 per cent under orchards and 1.38 per cent under plantation crops. The jhum cycle practiced in this part of Arunachal Pradesh is 10 to 12 years and hence the total landholding for a single family is quiet large. However, the land under cultivation in one agricultural year is relatively small.

Agriculture in Tirap is also mostly at subsistence level except for a few entrepreneurs that commercially cultivate tea. Commercial cultivation of large cardamom is also a relatively new practice that has taken root in this area since the last decade and is rapidly gaining popularity due to its low input requirement and greater income per unit area. Other than tea and large cardamom, the other commercial crops grown in this area are, oranges, bamboo and Assam fan-palm. Land under non-agricultural use constitutes only about 1.87 per cent of the total area.

In this particular study, an attempt was made to identify the various problems faced by the large cardamom growers in production and marketing of large cardamom in the area under study. The problems were found to be common for all the respondents and hence the study was carried out in general and not according to different categories. Ranking the problems according to number of respondents facing the problem in production of large cardamom showed that the lack of knowledge about scientific methods of cultivation was ranked first with 100.00 per cent of the respondents facing this problem.

A large number of respondents (97.00 per cent) faced the problem of lack of proper trainings in production as well as post harvest handling if produce, placing this problem in the second rank. Identification and management of insect pest and diseases is also a major hurdle that the producers face during production. Foorky disease of large cardamom is a major viral disease that was observed in the fields. However farmers have no knowledge about the cause and management of the disease. Also, management of viral disease requires incineration of the infected plants and it is difficult to persuade the growers to do that. The study also revealed that 90.00 per cent of the respondents face the problem of lack of availability of quality planting materials and had no knowledge of raising a nursery for growing healthy saplings. Some of the other minor problems faced by the growers included lack of government support, lack of availability and lack of availability of funds (Table 1-14). 
Table.1 Area and production of large cardamom in Arunachal Pradesh

\begin{tabular}{|l|c|c|c|}
\hline YEAR & $\mathbf{2 0 0 8 - 2 0 0 9}$ & $\mathbf{2 0 1 1 - 2 0 1 2}$ & $\mathbf{2 0 1 2 - 2 0 1 3}$ \\
\hline AREA(ha) & 12,452 & 13,920 & 14,770 \\
\hline PRODUCTION (MT) & 648 & 2,784 & 2,954 \\
\hline
\end{tabular}

Table.2 Area and production of large cardamom in Tirap district of Arunachal Pradesh

\begin{tabular}{|c|c|c|}
\hline YEAR & $\mathbf{2 0 1 4 - 2 0 1 5}$ & $\mathbf{2 0 1 5 - 2 0 1 6}$ \\
\hline AREA (ha) & 290 & 295 \\
\hline PRODUCTION (MT) & 120 & 136 \\
\hline
\end{tabular}

(Source: official records of the District Horticultural Officer on the area and production of major horticultural crops in Tirap district of Arunachal Pradesh)

Table.3 Category of respondents

\begin{tabular}{|c|c|}
\hline CATEGORY & LAND UNDER LARGE CARDAMOM CULTIVATION (ha) \\
\hline CATEGORY 1 & 0.01 to 0.5 \\
\hline CATEGORY 2 & 0.50 to 1.46 \\
\hline CATEGORY 3 & 0.47 and above \\
\hline
\end{tabular}

Table.4 Distribution of respondents according to different age groups

\begin{tabular}{|l|c|c|c|c|c|c|c|}
\hline CATEGORY & \multicolumn{2}{|c|}{$(<\mathbf{4 0}$ yrs $)$} & \multicolumn{2}{c|}{$(\mathbf{4 1 - 6 0}$ yrs $)$} & \multicolumn{2}{c|}{$(=\mathbf{6 1 <} \mathbf{y r s})$} & \\
\cline { 2 - 9 } & $\begin{array}{c}\text { FREQU } \\
\text { ENCY }\end{array}$ & AERCENT & FREQU & PERCENT & FREQU & PERCENT & TOTAL \\
& ENCY & AGE $(\%)$ & ENCY & AGE $(\%)$ & \\
\hline CATEGORY 1 & 16 & 61.54 & 6 & 23.08 & 4 & 15.38 & 26 \\
\hline CATEGORY 2 & 14 & 31.11 & 28 & 62.22 & 3 & 6.67 & 45 \\
\hline CATEGORY 3 & 19 & 65.52 & 5 & 17.24 & 5 & 17.24 & 29 \\
\hline \multicolumn{1}{|c|}{ TOTAL } & 49 & 49.00 & 39 & 39.00 & 12 & 12.00 & 100 \\
\hline
\end{tabular}

Table.5 Distribution of respondents and their family members according to gender

\begin{tabular}{|c|c|c|c|c|}
\hline \multirow{2}{*}{ CATEGORY } & \multicolumn{2}{|c|}{ RESPONDENTS } & \multicolumn{2}{c|}{ RESPONDENT'S FAMILY } \\
\cline { 2 - 5 } & FREQUENCY & PERCENTAGE (\%) & FREQUENCY & PERCENTAGE (\%) \\
\hline MALE & 88 & 88.00 & 190 & 37.77 \\
\hline FEMALE & 12 & 12.00 & 184 & 36.58 \\
\hline CHILDREN & 00 & 0.00 & 129 & 25.65 \\
\hline
\end{tabular}


Table.6 Family size of the respondents

\begin{tabular}{|l|c|c|c|c|c|c|c|}
\hline & $\begin{array}{c}\text { NO. OF } \\
\text { FAMILIES }\end{array}$ & $\begin{array}{c}\text { AVERAG } \\
\text { E SIZE OF } \\
\text { THE } \\
\text { FAMILY }\end{array}$ & $\begin{array}{c}\text { MAXIM } \\
\text { UM SIZE } \\
\text { OF } \\
\text { FAMILY }\end{array}$ & $\begin{array}{c}\text { MINIMU } \\
\text { M SIZE } \\
\text { OF } \\
\text { FAMILY }\end{array}$ & $\begin{array}{c}\text { AVERAG } \\
\text { E NO OF } \\
\text { ADULT } \\
\text { MALES } \\
\text { PER }\end{array}$ & $\begin{array}{c}\text { AVERAGE } \\
\text { NO OF } \\
\text { ADULT } \\
\text { FEMALES } \\
\text { FER }\end{array}$ & $\begin{array}{c}\text { AVERAG } \\
\text { E NO. OF } \\
\text { CHILDR } \\
\text { EN PER } \\
\text { FAMILY } \\
\text { FAMILY }\end{array}$ \\
\hline CATEGORY 1 & 26 & 5.38 & 9 & 3 & 2.08 & 1.88 & 1.42 \\
\hline CATEGORY 2 & 45 & 5.13 & 8 & 3 & 1.93 & 1.96 & 1.24 \\
\hline CATEGORY 3 & 29 & 4.55 & 7 & 2 & 1.69 & 1.62 & 1.24 \\
\hline
\end{tabular}

Table.7 Family composition of the respondents

\begin{tabular}{|c|c|c|c|c|c|c|c|}
\hline CATEGORY & MALE & $\begin{array}{c}\text { PERCENTAGE } \\
(\boldsymbol{\%})\end{array}$ & FEMALE & $\mathbf{( \% )}$ & CHILDREN & $(\boldsymbol{\%})$ & TOTAL \\
\hline CATEGORY 1 & 54 & 38.57 & 49 & 35 & 37 & 26.43 & 140 \\
\hline CATEGORY 2 & 87 & 37.66 & 88 & 38.10 & 56 & 24.24 & 231 \\
\hline CATEGORY 3 & 49 & 37.12 & 47 & 35.61 & 36 & 27.27 & 132 \\
\hline TOTAL & 190 & 37.77 & 184 & 36.58 & 129 & 25.65 & 503 \\
\hline
\end{tabular}

Table.8 Distribution of the respondents and their family members as per their education

\begin{tabular}{|c|c|c|c|c|}
\hline LEVEL OF & \multicolumn{3}{|c|}{ RESPONDENTS } & \multicolumn{2}{c|}{$\begin{array}{c}\text { RESPONDENTS'S FAMILY } \\
\text { MEMBERS }\end{array}$} \\
\cline { 2 - 5 } EDUCATION & NOS. & PERCENTAGE (\%) & NOS. & PERCENTAGE (\%) \\
\hline ILLITERATE & 40 & 40.00 & 140 & 27.83 \\
\hline PRIMARY & 49 & 49.00 & 237 & 47.12 \\
\hline HIGHER & 11 & 11.00 & 119 & 23.66 \\
\hline SECONNDARY & & 0.00 & 7 & 1.39 \\
\hline GRADUATE & 0 & & & \\
\hline
\end{tabular}


Int.J.Curr.Microbiol.App.Sci (2018) 7(5): 2561-2573

Table.11 Land distribution and land use pattern (ha)

\begin{tabular}{|c|c|c|c|c|c|c|c|c|c|c|c|}
\hline \multirow[b]{2}{*}{ 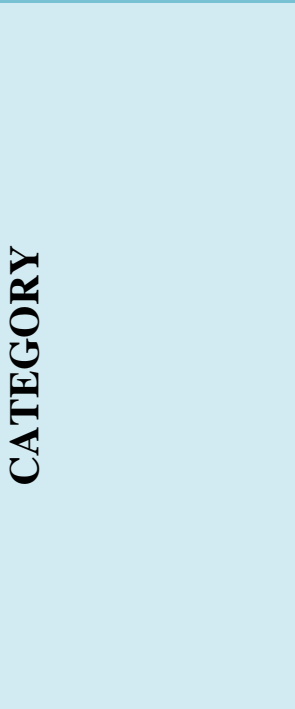 } & \multirow[b]{2}{*}{ 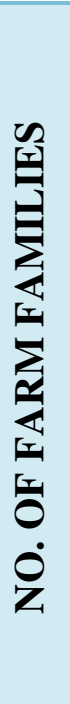 } & \multirow{2}{*}{ 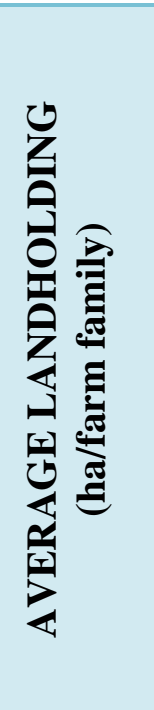 } & \multirow{2}{*}{ 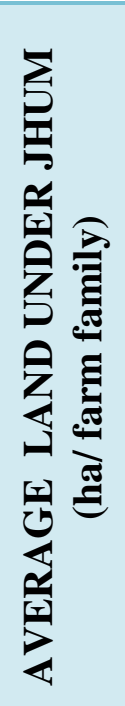 } & \multirow{2}{*}{ 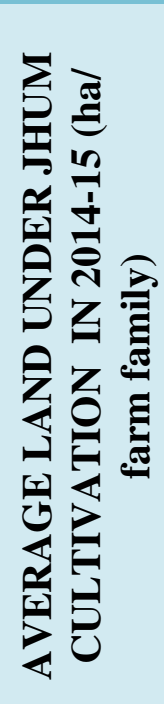 } & \multicolumn{5}{|c|}{ LAND UNDER AGRICULTURE } & \multicolumn{2}{|c|}{$\begin{array}{c}\text { LAND UNDER } \\
\text { NON } \\
\text { AGRICULTURAL } \\
\text { USE }\end{array}$} \\
\hline & & & & & 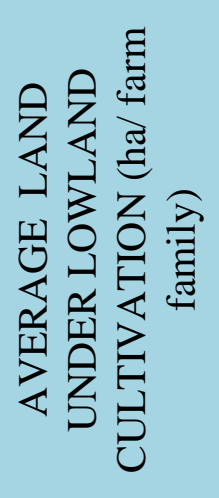 & 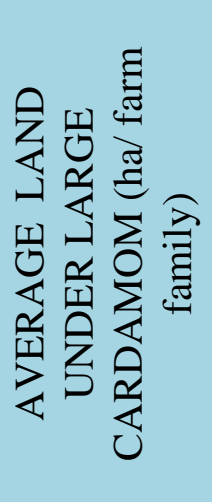 & 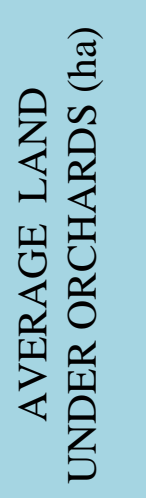 & 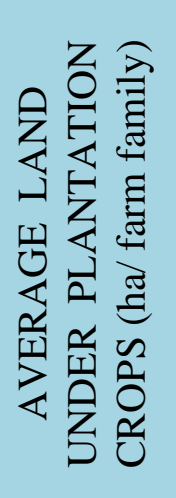 & 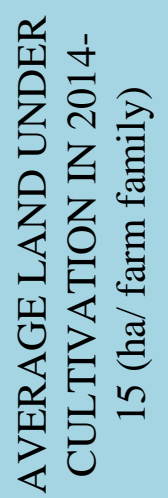 & 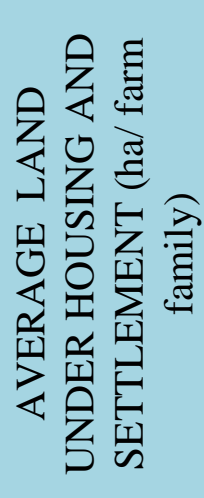 & 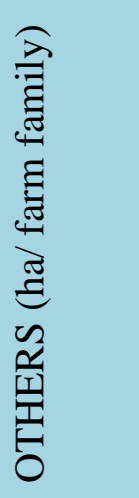 \\
\hline CATEGORY 1 & 26 & 10.72 & 9.35 & 1.63 & 0.41 & 0.44 & 0.20 & 0.13 & 2.81 & 0.15 & 0.010 \\
\hline CATEGORY 2 & 45 & 10.30 & 8.91 & 1.54 & 0.07 & 0.96 & 0.03 & 0.14 & 2.75 & 0.19 & 0.011 \\
\hline CATEGORY 3 & 29 & 9.66 & 7.61 & 1.16 & 0.00 & 1.61 & 0.05 & 0.14 & 2.96 & 0.23 & 0.005 \\
\hline SD & & 1.68 & 1.78 & 0.63 & 0.27 & 0.49 & 0.34 & 0.21 & 0.71 & 0.12 & 0.04 \\
\hline
\end{tabular}


Table.12 Land distribution and land use pattern (\%)

\begin{tabular}{|l|l|l|l|l|l|l|l|l|}
\hline & \multicolumn{9}{|c|}{ LAND UNDER AGRICULTURE } & LAND UNDER NON \\
AGRICULTURAL USE \\
\hline
\end{tabular}


Table.9 Distribution of the sample population according to their economic status

\begin{tabular}{|c|c|c|c|c|c|c|c|}
\hline CATEGORY & E & $\begin{array}{c}\text { PERCENTAGE } \\
(\mathbf{\%})\end{array}$ & ED & $\begin{array}{c}\text { PERCENTAGE } \\
(\mathbf{\%})\end{array}$ & $\mathbf{D}$ & $\begin{array}{c}\text { PERCENTAGE } \\
(\mathbf{\%})\end{array}$ & TOTAL \\
\hline CATEGORY 1 & 48 & 34.29 & 8 & 5.71 & 84 & 60 & 140 \\
\hline CATEGORY 2 & 78 & 33.77 & 12 & 5.19 & 141 & 61.04 & 231 \\
\hline CATEGORY 3 & 49 & 37.12 & 11 & 8.33 & 72 & 54.55 & 132 \\
\hline TOTAL & 175 & 34.79 & 31 & 6.16 & 297 & 59.05 & 503 \\
\hline
\end{tabular}

$(\mathrm{E}=$ Earner, $\mathrm{ED}=$ Earner-dependent and $\mathrm{D}=$ Dependent $)$

Table.10 Primary and secondary occupations of the farm family

\begin{tabular}{|c|c|c|c|c|}
\hline \multirow{2}{*}{ OCCUPATION } & \multicolumn{2}{|c|}{ PRIMARY OCCUPATION } & \multicolumn{2}{c|}{ SECONDARY OCCUPATION } \\
\cline { 2 - 5 } & NOS. & PERCENTAGE $(\%)$ & NOS. & PERCENTAGE $(\%)$ \\
\hline AGRICULTURE & 94 & 94.00 & 7 & 22.58 \\
\hline SERVICE & 4 & 4.00 & 0 & 0.00 \\
\hline BUSINESS & 2 & 2.00 & 10 & 32.26 \\
\hline OTHERS & 0 & 0.00 & 14 & 45.16 \\
\hline
\end{tabular}

$(\mathrm{E}=$ Earner, $\mathrm{ED}=$ Earner-dependent and $\mathrm{D}=$ Dependent $)$

Table.13 Problems faced during the production of large cardamom

\begin{tabular}{|c|l|c|c|}
\hline Sl.no. & \multicolumn{1}{|c|}{ CONSTRAINTS } & $\begin{array}{c}\text { PERCENTAGE } \\
(\mathbf{\%})\end{array}$ & RANK \\
\hline $\mathbf{1 .}$ & $\begin{array}{l}\text { Lack of knowledge about scientific methods of } \\
\text { cultivation }\end{array}$ & 100 & $1^{\text {st }}$ \\
\hline $\mathbf{2 .}$ & $\begin{array}{l}\text { Lack of proper trainings in production as well as post } \\
\text { harvest handling if produce. }\end{array}$ & 97 & $2^{\text {nd }}$ \\
\hline $\mathbf{3 .}$ & $\begin{array}{l}\text { Insect, pest and disease incidence. } \\
\text { 4. }\end{array}$ & $\begin{array}{l}\text { Lack of knowledge about identification and control } \\
\text { of pest and diseases. }\end{array}$ & 96 \\
\hline $\mathbf{5 .}$ & Lack of availability of insecticides / pesticides. & 96 & $3^{\text {rd }}$ \\
\hline $\mathbf{6 .}$ & $\begin{array}{l}\text { Lack of quality planting materials (HYV, disease and } \\
\text { pest resistant varieties) }\end{array}$ & 90 & $3^{\text {th }}$ \\
\hline $\mathbf{7 .}$ & Lack of affordability of insecticides / pesticides & 35 & $5^{\text {th }}$ \\
\hline $\mathbf{8 .}$ & Lack of government support. & 30 & th \\
\hline $\mathbf{9 .}$ & Lack of availability of FYM. & 18 & 8 th \\
\hline $\mathbf{1 0 .}$ & Availability of Funds and capital. & 8 & 9 th \\
\hline
\end{tabular}


Table.14 Problems faced in marketing of large cardamom

\begin{tabular}{|c|l|c|c|}
\hline Sl.no. & \multicolumn{1}{|c|}{ CONSTRAINTS } & PERCENTAGE (\%) & RANK \\
\hline $\mathbf{1 .}$ & $\begin{array}{l}\text { Post harvest losses due to lack of knowledge about } \\
\text { post harvest handling of produce including cleaning } \\
\text { and curing. }\end{array}$ & 100 & 1 st \\
\hline $\mathbf{2 .}$ & Lack of good storage facilities. & 100 & 1 st \\
\hline $\mathbf{3 .}$ & Lack of awareness about market information & 98 & 2nd \\
\hline $\mathbf{4 .}$ & $\begin{array}{l}\text { Lack of proper knowledge and skill in sorting and } \\
\text { grading of produce. }\end{array}$ & 98 & 2nd \\
\hline $\mathbf{5 .}$ & Lack of good transportation facilities. & 85 & 3rd \\
\hline $\mathbf{6 .}$ & High transportation cost. & 84 & 4th \\
\hline $\mathbf{7 .}$ & Distance of the market from the fields. & 70 & 5th \\
\hline
\end{tabular}

A similar ranking of the various problems faced by the large cardamom growers in marketing of the produce showed that the most severe problem faced by all the respondents was post harvest losses due to lack of proper knowledge about curing of the harvested crop along with lack of proper storage facilities, leading to a large quantity of the produce getting perished before reaching the market. 98.00 percent of the growers faced the problem if lack of awareness about market information. Lack of good transportation facilities, high transportation cost and distance of the market from the farm were the other major problem faced by the farmers.

In conclusion, the study brought in to light the various socio-agro-economic and demographic details of the farm households involved in the cultivation of large cardamom along with the various problems faced by them in production as well as marketing of the crop. It was found that a majority of the respondents (49.00 per cent) were under the age group below 40 years followed by 39.00 percent in the age group between 41-60 years and 12.00 per cent in the age group above 61 years with more females than males in the study area with the male: female ratio being
0.96. The average size of the family in the farm household was found to be 5.00, while the 27.83 per cent of the sample population under study were found to be illiterate, 47.12 per cent were educated to primary level, 23.66 per cent till high-school level and a mere amount of 1.39 per cent till graduation level. The earners of the family constituted 34.79 per cent of the sample under study, 6.16 per cent were earner/dependents and a large portion i.e. 59.05 per cent were dependents.

It was observed that the farm families under study were primarily engaged in agriculture (94.00 per cent) and only 4.00 per cent and 2.00 per cent were engaged in service and business respectively for their primary source of income with most of the land used for jhum / shifting cultivation constituting 84.58 per cent of the total land holding and only 27.65 per cent of the total landholding was used for cultivation in the year 2014-15. 9.90 per cent of the total landholding was found to be under large cardamom cultivation, 1.38 per cent under plantation crops and 1.36 per cent under lowland rice cultivation. The study showed that lack of knowledge and training about the scientific cultivation of the crop, inability to identify and manage insect peats and diseases and lack of quality planting 
materials were the major problems faced by the growers in the production of large cardamom in the study area. Whereas, lack of technical know-how about post harvest handling of produce, curing, sorting, grading and lack of good storage facilities leading to huge post harvest losses along with lack knowledge about market information, lack of good transportation facilities and high transportation cost were some of the major constraints faced by the farmers in the marketing of large cardamom. It was noteworthy that none of the growers are the beneficiaries of any kind of help from the Spice Board of India during the period of the study and it can be said that any future help from the spice board would help bring positive changes in the production and marketing of large cardamom in this part of the country.

\section{Suggestions}

The findings of the led to the drawing of some viii. suggestions for improving the production, increasing the productivity and efficient marketing of large cardamom that can help in improving the socio-economic status and standard of living of the large cardamom growers. The following suggestions may be recommended based on the study of the constraints faced by the growers in the production and marketing of large cardamom.

i. Govt should provide the growers with the necessary training facilities for scientific cultivation of large cardamom.

ii. Farmers should be taught to identify and control insect-pest and disease incidence at an early controllable stage and they should be introduced to INM, IPM and IDM.

iii. Farmers need to be trained in post harvest handling if produce, like sorting, grading and curing to avoid post-harvest losses.

iv. Broadcasting of market information in radios and television is an essential step in raising awareness about the up to date market information amongst the growers.

v. Construction of durable storage houses that can protect the produce from harsh weather and climate

vi. The traditional methods of drying the capsules include sun drying and drying over the fire. They both have disadvantages as the produce rots fast during rainy and overcast days when the produce is dried outside in the open. Also, when the crop is dried over the fire, the spice loses some of its flavor and hence the quality is lowered. Therefore, it is required that bhattis or other improved dryers be constructed or installed in the villages and the villagers be taught to use them to their advantage.

vii. Promoting cooperative methods of marketing among the growers is essential in order to reduce marketing cost of the producers.

Provision of better transportation facilities, better roads and reasonable transportation cost will encourage the growers to strive better and also encourage other farmers to start large cardamom cultivation.

It would help the growers to increase the production and productivity of the crop if the Spice Board of India would lend them help in the form of technology and technical knowhow.

\section{References}

Anonymous, Wikipedia. The free encyclopaedia, https://en.wikipedia.org/ wiki/Black_cardamom

Arunachal Pradesh at a glance - 2013. Directorate of Economics and Statistics, Government of Arunachal Pradesh, Itanagar. 
Avasthe, R.K., Singh, K.K. and Tomar, J.M.S. 2011. Large cardamom (Amomum subulatum Roxb.) based agroforestry systems for production, resource conservation and livelihood security in the Sikkim Himalaya. Indian Journal of Soil Conservation. 39(2):155-160.

Bhutia, Pemba. H., Sharangi, A.B., Lepcha, R. and Yonzone, R. 2018. Post-harvest and value chain management of large cardamom in hills and uplands. International Journal of Chemical Studies 6(1): 505-511

Economic review of Arunachal Pradesh-2013. Directorate of Economics and Statistics, Government of Arunachal Pradesh, Itanagar.

Sharma, E., Chettri, N., Tshering, K., Jing, F., Mool, P. and Eriksson, M. 2009.
Climate change impacts and vulnerability in the Eastern Himalayas. ICIMOD: Kathmandu.

Sharma, G., Sharma, R. and Sharma, E. 2009. Traditional knowledge systems in large cardamom farming: Biophysical and management diversity in Indian mountainous regions. Indian Journal of Traditional Knowled. 8(1):17-22.

Statistical abstract of Arunachal Pradesh2013.Directorate of Economics and Statistics, Government of Arunachal Pradesh, Itanagar.

Stoep, G.A.V. 2010. Enhancing Competitiveness of Nepal's Large Cardamom Value Chain. Kathmandu, Nepal: SNV Netherlands Development Organization.

\section{How to cite this article:}

Avicha Tangjang and Amod Sharma 2018. Problem Faced by the Large Cardamom Growers during Production and Marketing: A Case Study of Tirap District of Arunachal Pradesh. Int.J.Curr.Microbiol.App.Sci. 7(05): 2561-2573. doi: https://doi.org/10.20546/ijcmas.2018.705.295 